Int. J. Odontostomat., 5(3):293-299, 2011.

\title{
Ameloblastoma: Report of Two Cases and a Brief Literature Review
}

\author{
Ameloblastoma: Presentación de Dos Casos y una Breve Revisión de la Literatura \\ Lucinei Roberto Oliveira*; Bruno Henrique Figueiredo Matos*; Paulo Roberto Dominguete*; Verônica Assalin \\ Zorgetto $^{* *}$ \& Alfredo Ribeiro-Silva**
}

OLIVEIRA, L. R.; MATOS, B. H. F.; DOMINGUETE, P. R.; ZORGETTO, V. A. \& RIBEIRO-SILVA, A. Ameloblastoma: report of two cases and a brief literature review. Int. J. Odontostomat., 5(3):293-299, 2011.

\begin{abstract}
Ameloblastoma is an uncommon odontogenic neoplasm that accounts for approximately $10 \%$ of all tumors originating from gnathic bones. Although its growth is localized, the tumor can also be infiltrative and persistent; however, its behavior is usually benign. The mandible is the most commonly affected site, and ameloblastoma is most frequently diagnosed between the fourth and fifth decades of life. In addition to a brief review of the literature, the present study discusses the clinical, imaging, histopathological and prognostic characteristics of these tumors by presenting two case reports. In these cases, the patients were aged 40 and 66 years, of different sexes and ethnicities and presented with the same complaint regarding localized and asymptomatic swelling. Both cases occurred in the posterior region (but on opposite sides) of the mandible. The patients were initially subjected to clinical examination and imaging of the face, followed by incisional biopsy to confirm (in both cases) the diagnosis of multicystic intraosseous ameloblastoma with a plexiform pattern. Both patients were treated by wide resection of the lesion (with safety margins), and only one patient experienced tumor recurrence. After 42 and 68 months of follow-up, the patients are still alive and show no signs of recurrence. Clinical and imaging findings aid in the differential diagnosis of ameloblastomas; however, histopathological evaluation is essential for its definitive diagnosis. Early diagnosis and precise detection of the borders to provide adequate safety margins during the surgical resection of the tumor are necessary to achieve successful treatment and recurrence-free survival for solid ameloblastomas.
\end{abstract}

KEY WORDS: ameloblastoma, jaw neoplasms, odontogenic tumor.

\section{INTRODUCTION}

Ameloblastoma is an uncommon epithelial odontogenic neoplasm that is non-mineralized, locally aggressive and, in most cases, benign. Ameloblastoma accounts for approximately $10 \%$ of all tumors that originate in the maxilla and mandible (Becelli et al., 2002; Zemann et al., 2007). This neoplasm is most commonly found in young adults and usually demonstrates no sex predilection. Some studies have suggested a greater frequency of ameloblastoma in individuals of African descent; however, other studies have demonstrated the absence of a racial predilection. Although the tumor has been recognized for many years, the etiology of the disease remains unclear (Reichart et al., 1995; Kumamoto \& Ooya, 2006; Zemann et al.).
Ameloblastoma is an intraosseous odontogenic neoplasm of great interest due to its ability to aggressively infiltrate the maxillofacial region; this infiltration may causes severe trauma and, in some cases, poses a risk to the patient's life (Reichart et al.; Becelli et al.).

\section{CASE REPORT}

Case 1. A 66-years-old melanoderma female patient sought treatment at the General Hospital in Ribeirao Preto Medical School of the São Paulo University due to a localized swelling and asymptomatic intraoral lesion on the posterior region of the left inferior alveolar ridge. The

\footnotetext{
"Vale do Rio Verde University, Tres Corações, Minas Gerais, Brazil.

** Department of Pathology, Ribeirao Preto Medical School, University of São Paulo, Brazil.
} 
lesion exhibited no bleeding and a slow and progressive evolution of approximately six months; however, the time since the lesion was noticed was undetermined.

No signs of facial asymmetry were noted on an extra-oral physical examination. Oroscopy revealed that the patient was edentulous and used upper and lower dentures. A localized intraosseous cavitary lesion was observed on the left inferior alveolar ridge that was approximately $30 \mathrm{~mm}$ in diameter and below the mucosa and that had an oval shape, a wrinkled and ulcerated surface and a soft and firm consistency. The edges of the lesion were irregular and undefined. No palpable lymph nodes were noticed on palpation of the submaxillary and cervical chains. Following clinical examination, the patient was subjected to radiographic examination and computed tomography (Fig. 1), which revealed the location of the tumor.

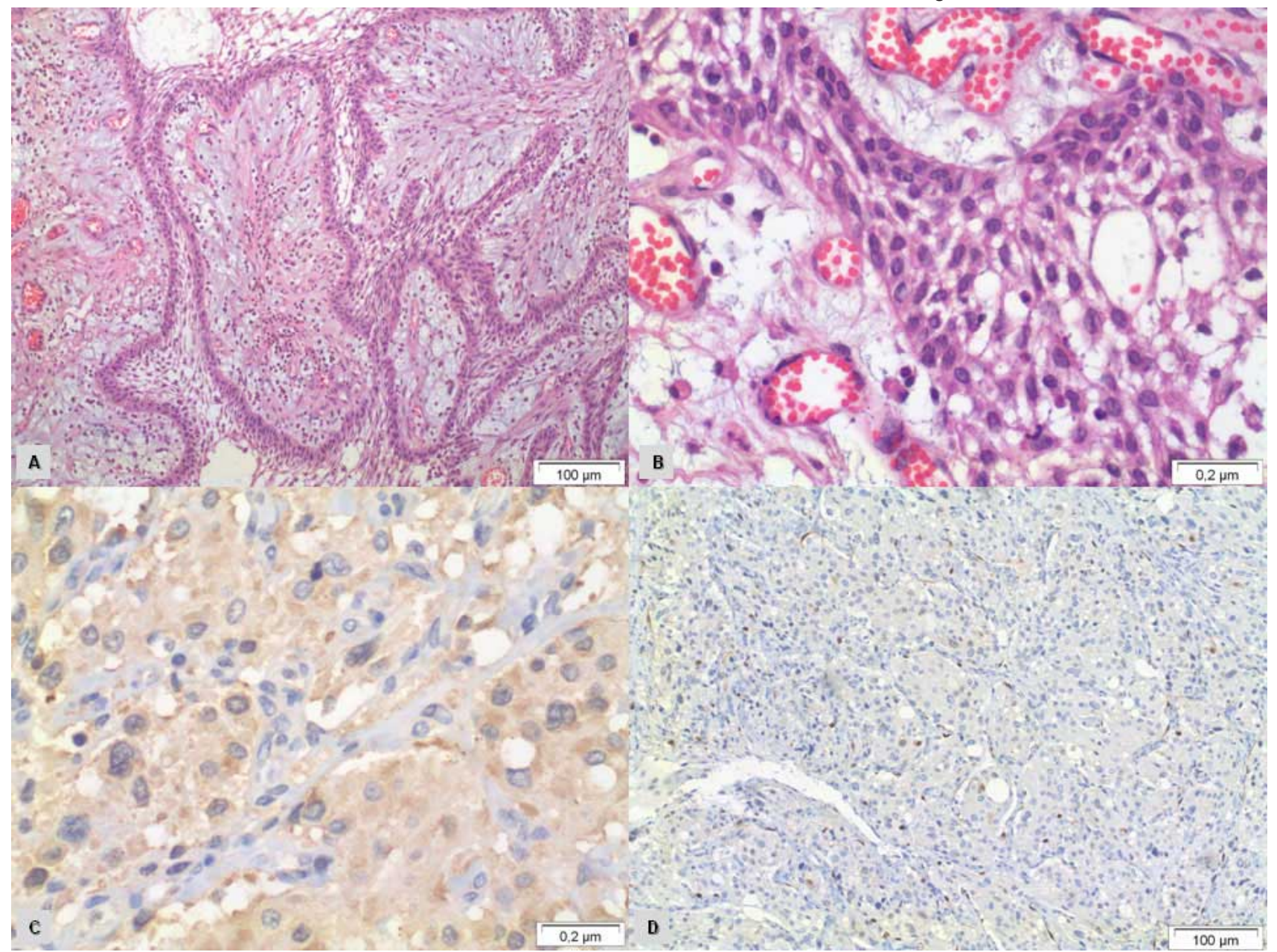

Fig. 2. (A) Long anastomosing cords of odontogenic epithelium outlining portions of stroma, which is characteristic of ameloblastomas with a plexiform pattern (Hematoxylin and Eosin (H/E), 100x). (B) Cords of odontogenic epithelium enclosed by columnar or cubic cells, which are similar to ameloblasts (H/E, 400x). (C) Neoplastic cells positive for neuron-specific enolase (NSE) (intra-cytoplasmic staining, 400x). (D) Neoplastic cells showing no reactivity to S100 (100x). 
Incisional biopsy was performed, and histopathology confirmed the final diagnosis of multicystic intraosseous ameloblastoma with a plexiform pattern (Fig. 2, A-D). The patient underwent a surgical procedure for "en bloc" resection of the lesion with complete removal of the tumor and safety margins of approximately $15 \mathrm{~mm}$, which were tumor-free. The patient is alive and has been monitored for 42 months. To date, this patient remains free of any signs of recurrence following clinical and imaging examinations periodically and she has received prosthetic rehabilitation with functional and aesthetic satisfaction.

Case 2. A 40-years-old leucoderma male patient sought treatment at the Surgical Center of the Vale do Rio Verde University (UninCor), Três Corações, Minas Gerais, complaining of a localized and asymptomatic swelling in the region of the right posterior mandibular body. The patient was unable to report the time evolution of the lesion, and the extra-oral physical examination was normal. However, during an intra-oral examination, a discrete nodular mass of approximately $5 \mathrm{~mm}$ in diameter was noticed on the right inferior vestibular alveolar mucosa (apical region of the first premolar), with a smooth surface, normal color, irregular margins and a fibrous consistency on palpation. Radiographic examination revealed a radiolucent lesion with irregular margins in the right inferior premolar region that was associated with an area of bone destruction, with invasion of the mandibular canal and preservation of the basal cortex (Fig. 3). After incisional biopsy was confirmed the diagnosis of multicystic ameloblastoma with a plexiform pattern, and the patient was subjected to a surgical procedure for the segmental resection of the lesion, with safety margins of approximately $15 \mathrm{~mm}$. The surgical specimen was again submitted to histopathological analysis, which verified that the margins were tumor-free.

Sixty months after the primary lesion was diagnosed, the patient noticed a swelling in the right posterior mandibular region. A radiographic examination revealed the recurrence of the tumor with bone destruction and involvement of the basal mandibular cortex, which was confirmed by histopathology. Surgical resection of the right mandible was then performed, preserving only the condyle and the coronoid process on the right side, with reconstruction plate fixation (Fig. $3)$. After 68 months of follow-up, the patient currently undergoes 6-month follow-ups and shows no signs of tumor recurrence.

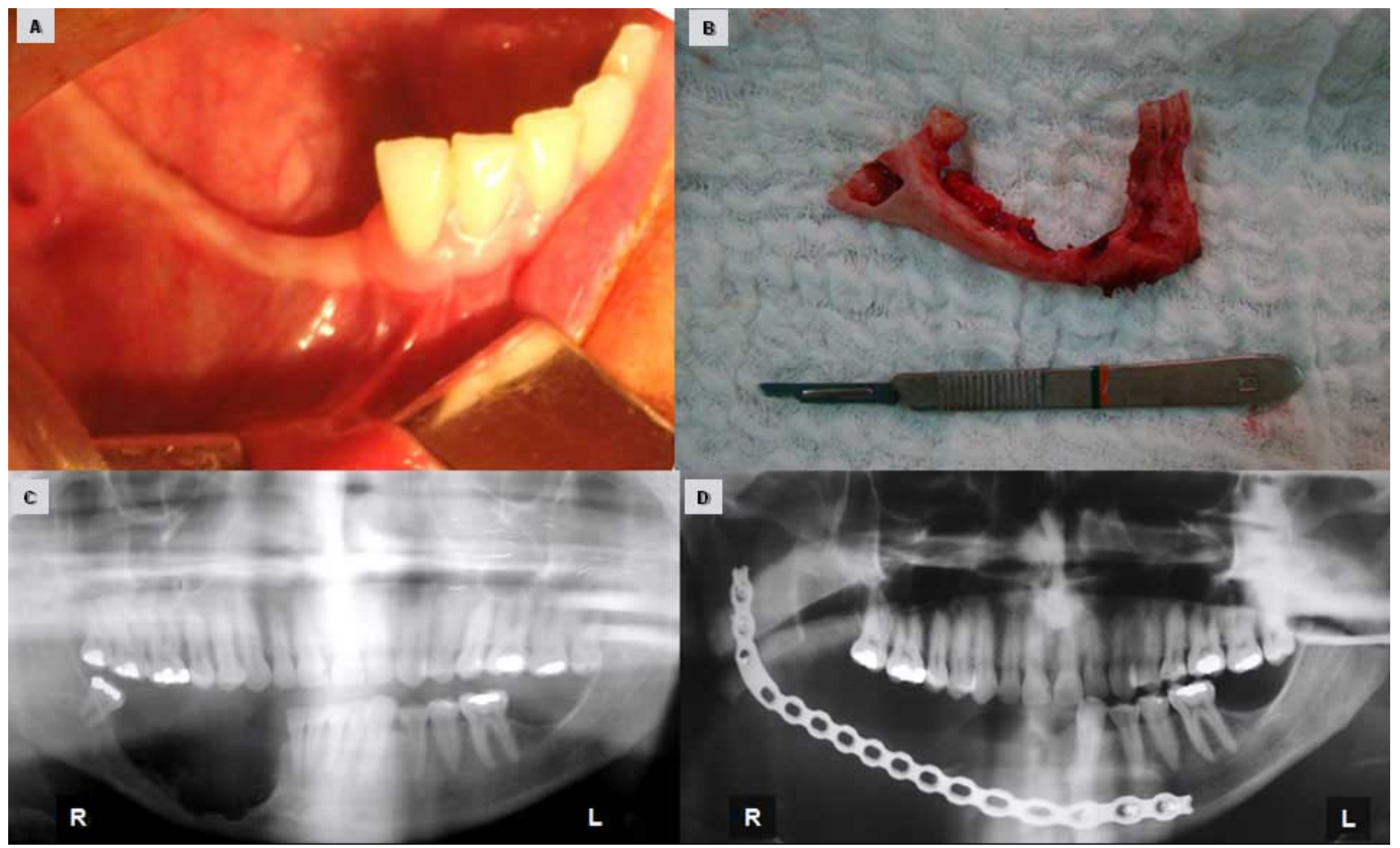

Fig. 3. (A) A discrete nodular mass with approximately $5 \mathrm{~mm}$ in diameter in the right inferior vestibular alveolar mucosa. (B) The surgical procedure for the resection of the mandible on the right side. (C) An initial radiolucent lesion with irregular margins in the right inferior premolar region. (D) A current panoramic radiograph after 68 months of follow-up with reconstruction plate fixation, indicating the absence of recurrence. 


\section{DISCUSSION}

Ameloblastomas originate from epithelial remnants of dental embryogenesis, without the participation of the odontogenic ectomesenchyme (Martinez et al., 2008). This tumor was initially considered to be a type of odontogenic cyst and was first described by Cusak (1827) in a case report of mandibulectomy, and later reported by Broca (1866) and Falksson (1879). The classic study by Malassez (1885) ultimately differentiated the tumor from other types of cyst and gave it the name 'adamantinoma'. The term ameloblastoma was later suggested by lvy \& Churchill (1960), based on an analysis of the odontogenic epithelium involvement in the tumor origin. According to the literature, potential sources of this specialized epithelium may also include embryonic odontogenic rests (rests of Malassez and rests of Serres), the epithelial lining of odontogenic cysts (especially the dentigerous cyst) and basal cells from the oral mucosa (Adekeye \& Lavery, 1986; Gardner, 1996; Olaitan et al., 1998). However, the trigger for neoplastic transformation of these epithelial structures remains unknown (Olaitan et al.; Al-Khateeb \& Ababneh, 2003).

Although a wide variation in the range of ages can be observed, ameloblastoma primarily affects young adults between the fourth and fifth decades of life. Unlike the observation in the first case report (Case 1), the mean age is most commonly between 35 and 45 years (Adekeye \& Lavery; Reichart et al.; Becelli et al.).

Ameloblastoma is usually included in the differential diagnosis according to the presentation of the patient's history and clinical characteristics. The diagnosis of ameloblastoma is suggested by nonspecific radiographic findings and a thorough locoregional physical examination. Nevertheless, a definitive diagnosis is only obtained through a histopathological exam (Antunes et al., 2006).

The persistent growth pattern (localized and infiltrative to the maxillofacial region) and the ability to produce pronounced deformities are clinical characteristics that contribute to the possible identification of ameloblastomas. The typical ameloblastoma begins as a slowly destructive asymptomatic and intraosseous expansion, being a lesion that tends to expand and infiltrate, rather than perforate the bone. However, the diagnosis can also be suggested through a routine radiographic examination (Medeiros et al., 2008). As observed in the above mentioned cases, unless the tumor becomes infected (Al-Khateeb \& Ababneh), it is rarely painful. When these tumors become symptomatic, the patient may experience pain or numbness, swelling, malocclusion, tooth mobility or secondary infection (Anjos et al., 2003; Martinez et al.).

Ameloblastomas can occur at any location in the mandible or maxilla, but the regions of the inferior molars and mandibular ramus are the most prevalent anatomical locations (80\%) (Reichart et al.; Martins et al., 1999; Becelli et al.). Larger tumors may rupture the bone cortex and infiltrate adjacent soft tissues on the lingual surface of the mandible (Pizer et al., 2002). When the tumor occurs in the maxilla, the posterior region is the most affected, and the evolution and invasion of the tumor may compromise the maxillary sinus and the orbit (Zwahlen et al., 2003).

Ameloblastomas occur in distinct clinical and radiographic situations, which need to be considered separately due to therapeutic and prognostic differences. These tumors are classified as solid or multicystic ( $86 \%$ of cases), unicystic ( $13 \%$ of cases) or peripheral or extraosseous (approximately $1 \%$ of cases). In addition, rare malignant subtypes with metastasis can occur (malignant ameloblastoma and ameloblastic carcinoma) (Antunes et al.; Medeiros et al.). This distinction is important because the treatment for a unicystic lesion can be more conservative due to its less aggressive behavior and usually smaller size than the solid or multicystic variant (Ord et al., 2002).

The most common radiographic findings are unilocular and multilocular masses, septation, association with unerupted teeth, loss of lamina dura and root resorption (Martinez et al.). The uni- and multilocular radiographic patterns result in the traditional division of ameloblastomas into the solid and cystic types (Antunes et al.). In solid or multicystic ameloblastomas, a multilocular radiolucent lesion with undefined borders is the most characteristic radiographic aspect (soap bubble or honeycomb appearance). In the unicystic type, the lesions usually appear as radiolucent areas with relatively well-defined borders that surround the crown of an impacted inferior third molar, resembling a dentigerous cyst. The peripheral extraosseous ameloblastomas are rare, and 
usually the peripheral ameloblastomas present themselves as painless, usually non-ulcerated lesions on the alveolar or gingival mucosa, which can be sessile or pedunculated and demonstrate a non-aggressive benign course. In general, unicystic and peripheral lesions do not invade the bone tissue, respond better to treatment and have low recurrence rates (Martinez et al.).

Unlike most cases, neither of the cases reported in this article showed the characteristic radiolucent multilocular images on initial clinical examination. However, even when an ameloblastoma shows the typical expansive multilocular aspect, the differential diagnosis can include a variety of odontogenic and nonodontogenic lesions with similar radiographic characteristics (aneurysmal bone cyst, odontogenic keratocyst, ameloblastic fibroma, odontogenic myxoma, giant cell lesions and brown tumor of hyperparathyroidism). When the lesion presents with a cystic, unilocular and well-defined aspect, the differential diagnosis is typically of odontogenic keratocyst, dentigerous cyst, residual and radicular cysts or even a traumatic bone cyst. Additionally, peripheral ameloblastomas may resemble lesions such as fistulas (parulis), pyogenic granulomas, peripheral giant cell lesions and peripheral odontogenic fibromas (Martins et al.; Riascos et al., 2005).

On rare occasions, ameloblastomas may exhibit malignant behavior and metastasize. However, the nomenclature for these tumors (malignant ameloblastoma and ameloblastic carcinoma) is still controversial (Antunes et al.). Both the nomenclature and the issue of malignancy in these neoplasms are problems that require lengthy discussions. Therefore, because these issues deserve special discussion, they will not be addressed in the present study.

The histopathology of ameloblastomas basically consists of the proliferation of epithelial cells arranged in variable patterns, which may occasionally coexist in the same tumor (Martinez et al.). The most frequent histopathological patterns are the follicular and plexiform subtypes (Anjos et al.; Mendenhall et al., 2007). Although rare, other histopathological patterns can also be observed, such as acanthomatous, granular cell, basal cell and desmoplastic (Mendenhall et al.).

In the plexiform pattern, interdigitating cords and irregular masses of epithelial cells surrounding small amounts of stroma of the stellate reticulum can be observed. The granular cell pattern is an aggressive lesion with a significant tendency to recur, and the neoplastic epithelial component exhibits cells with a finely granular cytoplasm, resembling the cells of the granular cell tumor. The basal cell ameloblastoma is the least common type and is composed of nests of uniform basaloid cells. In contrast, the desmoplastic pattern exhibits the formation of a densely collagenized stroma with several fibrous septa (Antunes et al.).

Clinical, imaging and histopathological examinations of the reported cases confirmed the diagnosis of a solid or multicystic ameloblastoma that contained histological features consistent with the plexiform pattern. As noted in Fig. 2, this pattern contains many cord-like structures and elongated islets surrounded by stratified peripheral columnar cells of varying heights. These features are comparable to preameloblasts, which partially circumscribe tissue similar to the stellate reticulum and confer an appearance that resembles that of the enamel organ. Unlike previously reported for granular cell ameloblastomas (Kumamoto \& Ooya, 2001), the neoplastic cells were positive for neuron-specific enolase (NSE) in Case 1 (Fig. 2).

Because infiltration between the trabeculae of spongeous bone can occur, the recommended treatment for solid or multicystic ameloblastoma consists of wide resection to prevent recurrences and the possible progression to malignancy (Reichart et al.). A high recurrence rate, particularly after conservative treatments, is not uncommon for this type of odontogenic tumor (Medeiros et al.). Given these high recurrence rates, which vary between 50 and $90 \%$ after conservative treatment, several authors have supported surgical resection with safety margins for the treatment of solid or multicystic ameloblastomas and have advocated bone resection in the affected area with at least $15 \mathrm{~mm}$ of healthy adjacent tissue beyond the radiographic borders of the lesion (Anjos et al.; Martinez et al.), as performed in both of the above mentioned cases. The second patient is currently free of recurrences and was rehabilitated with reconstruction plate fixation (Fig. 3), as well as reported in other cases (Medeiros et al.).

In addition to the low radiosensitivity of this neoplasm, the intraosseous location of the ameloblastoma prevents the use of radiotherapy as an effective therapeutic option because radiation increases the potential development of secondary tumors (Reichart et al.; Olaitan et al.). To try to prevent the 
disfigurement of the patient, smaller unicystic lesions can be treated solely with enucleation and curettage, but recurrence occurs in an average of 10 to $20 \%$ of cases (Martinez et al.). Similarly, peripheral ameloblastomas exhibit innocuous clinical behavior and can be treated more conservatively because the local recurrence rate is $10 \%$. However, in all types of ameloblastomas, a thorough long-term clinical and radiographic follow-up is always recommended (Olaitan et al.; Becelli et al.), and these follow-ups were performed in both of the above mentioned cases.

Although clinical and imaging findings aid in the differential diagnosis, histopathological evaluation is essential for the definitive diagnosis of ameloblastomas. For successful treatment, early diagnosis and detection of the precise boundaries of the tumor are essential. However, due to the slow growth rate of these tumors and the ability to develop late recurrences, the recurrence events may occur several years after the initial primary tumor resection (Ferretti et al., 2000), and a long follow-up is recommended for patients diagnosed with this type of tumor, as performed in both reported cases in this study.

Summarizing, ameloblastomas are uncommon benign odontogenic neoplasms that rarely become malignant. In most cases, radical surgery is the treatment of choice for solid or multicystic ameloblastomas. Although several articles have been published on the subject, little is known regarding the biological behavior of this tumor, and a careful clinical examination combined with a thorough imaging investigation to evaluate the general aspects of the lesions and its margins, as well as its internal architecture and its relationship to adjacent anatomical structures, can assist in treatment planning. These informations coupled with the histopathological confirmation of the diagnosis will allow for the selection of the best individual therapeutic approaches, increasing the treatment efficacy in patients diagnosed with this tumor.

OLIVEIRA, L. R.; MATOS, B. H. F.; DOMINGUETE, P. R.; ZORGETTO, V. A. \& RIBEIRO-SILVA, A. Ameloblastoma: presentación de dos casos y una breve revisión de la literatura. Int. J. Odontostomat., 5(3):293-299, 2011.

RESUMEN: El ameloblastoma es un tumor odontogénico infrecuente que representa aproximadamente 10\% de todos los tumores que se originan a partir del maxilar y mandíbula. Aunque su crecimiento es localizado, el tumor puede ser infiltrante y persistente, y su comportamiento suele es benigno. La mandíbula es el sitio más comúnmente afectado, y el ameloblastoma se diagnostica con más frecuencia entre la cuarta y quinta década de la vida. Junto con una breve revisión de la literatura, el presente estudio analiza los datos clínicos, imágenes, características histopatológicas y pronóstico de estos tumores mediante la presentación de dos casos. En estos casos, los pacientes tenían entre 40 y 66 años, eran de diferentes sexos y grupos étnicos, que presentan la misma queja en relación con aumento de volúmen localizado y asintomática. Ambos casos ocurrieron en la región posterior (pero en lados opuestos) de la mandíbula. Los pacientes fueron sometidos inicialmente a un examen clínico e imagenológico, seguido de la biopsia incisional para confirmar (en ambos casos) el diagnóstico de ameloblastoma multiquístico intraóseo tipo plexiforme. Ambos pacientes fueron tratados con amplia resección de la lesión (con márgenes de seguridad), y sólo un paciente presentó recurrencia del tumor. Después de 42 y 68 meses de seguimiento, los pacientes están vivos y sin signos de recurrencia. Los resultados clínicos e imagenológicos ayudan en el diagnóstico diferencial del ameloblastomas, sin embargo, la evaluación histopatológica es esencial para su diagnóstico definitivo. El diagnóstico prematuro y la precisa detección de las márgenes de la lesión proporcionan márgenes de seguridad adecuadas durante la resección quirúrgica del tumor y son necesarios para lograr el éxito del tratamiento y la supervivencia libre de recurrencia en los ameloblastomas sólidos.

PALABRAS CLAVE: ameloblastoma, neoplasias maxilares y mandibulares, neoplasias odontogénicas.

\section{REFERENCES}

Adekeye, E. O. \& Lavery, K. M. Recurrent ameloblastoma of the maxillo-facial region. Clinical features and treatment. J. Maxillofac. Surg., 14:153-7, 1986.

Al-Khateeb, T. \& Ababneh, K. T. Ameloblastoma in Young Jordanians: A Review of the Clinicopathologic Features and Treatment of 10 Cases. J. Oral Maxillofac. Surg., 61:13-8, 2003.
Anjos, E.; Andrade, E.; Pinto, L. \& Souza, L. Estudo clínicopatológico de ameloblastomas: análise de casos. Rev. Bras. Patol. Oral, 60:224-8, 2003.

Antunes, A. A.; Silva, P. V.; Antunes, A. P. \& Romualdo Filho, J. Ameloblastoma: Estudo Retrospectivo. Rev. Bras. Cir. Cabeça Pescoço, 35:70-3, 2006. 
Becelli, R.; Carboni, A.; Cerulli, G.; Perugini, M. \& lannetti, G. Mandibular ameloblastoma: analysis of surgical treatment carried out in 60 patients between 1977 and 1998. J. Craniofac. Surg., 13:395-400, 2002.

Broca, P. Traité de tumeurs. Paris, Asselin, 1866.

Cusak, J. W. Report of the amputation of the portions of the lower jaw. Dubin Hosp. Rep., 4:1-38, 1827.

Falkson, R. Zur Kenntnis der Kiefercysten. Virchows Arch. Pathol. Anat. Physiol. Klin. Med., 76:504-10, 1879.

Ferretti, C.; Polakow, R. \& Coleman, H. Recurrent ameloblastoma: report of 2 cases. J. Oral Maxillofac. Surg., 58:800-4, 2000

Gardner, D. G. Some current concepts on the pathology of ameloblastomas. Oral Surg. Oral Med. Oral Pathol. Oral Radiol. Endod., 82:660-9, 1996.

Ivy, R. H. \& Churchil, H. R. The need of a standardized surgical and pathological classification of the tumors and anomalies of dental origin. Am. Assoc. Dent. Sch. Trans., $7: 240-5,1960$

Kumamoto, H. \& Ooya, K. Immunohistochemical and ultrastructural investigation of apoptotic cell death in granular cell ameloblastoma. J. Oral Pathol. Med., 30:245-50, 2001

Kumamoto, H. \& Ooya, K. Immunohistochemical detection of retinoblastoma protein and E2 promoter-binding factor-1 in ameloblastomas. J. Oral Pathol. Med., 35:183-9, 2006.

Malassez, L. Sur le role des debris épithéliaux paradentaires. Arch. Physiol. Norm. Pathol., 5:309-40, 1885.

Martinez, C. R.; Barros, R. M. G.; Orué, N. R.; Oliveira, J. G. P. \& Monteiro, J. C. C. Ameloblastoma: estudo clínicohistopatológico. Rev. Cir. Traumatol. Buco-Maxilo-Fac., 8:55-60, 2008.

Martins, R.; Sobrinho, J.; Rapoport, A. \& Rosa, M. Histopathologic features and management of ameloblastoma: study of 20 cases. Rev. Paul. Med., 117(4):171-4, 1999.

Medeiros, M.; Porto, G. G.; Laureano Filho, J. R.; Portela, L. \& Vasconcellos, R. H. Ameloblastoma em mandíbula. Rev. Bras. Otorrinolaringol., 74:478, 2008.

Mendenhall, W. M.; Werning, J. W.; Fernandes, R.; Malyapa, R. S. \& Mendenhall, N. P. Ameloblastoma. Am. J. Clin. Oncol., 30:645-8, 2007.

Olaitan, A. A.; Arole, G. \& Adekeye, E. O. Recurrent ameloblastoma of the jaws. A follow-up study. Int. J. Oral Maxillofac. Surg., 27:456-60, 1998.
Ord, R. A.; Blanchaert, R. H. Jr.; Nikitakis, N. G. \& Sauk, J. J. Ameloblastoma in Children. J. Oral Maxillofac. Surg., 60:762-71, 2002.

Pizer, M. E.; Page, D. G. \& Svirsky, J. A. Thirteen-year followup of large recurrent unicystic ameloblastoma of the mandible in a 15-year-old boy. J. Oral Maxillofac. Surg., 60:211-5, 2002.

Reichart, P. A.; Philipsen, H. P. \& Sonner, S. Ameloblastoma: biological profile of 3677 cases. Eur. J. Cancer B Oral Oncol., 31B:86-99, 1995.

Riascos, R.; Figueroa, R.; Martinez, F.; Martinez, S. \& Borrero, $\mathrm{L}$. Ameloblastoma de la región maxilo-mandibular. Rev. Colomb. Radiol., 16:1836-42, 2005.

Zemann, W.; Feichtinger, M.; Kowatsch, E. \& Kärcher, H. Extensive ameloblastoma of the jaws: surgical management and immediate reconstruction using microvascular flaps. Oral Surg. Oral Med. Oral Pathol. Oral Radiol. Endod., 103:190-6, 2007.

Zwahlen, R. A.; Vogt, P.; Fischer, F. S. \& Grätz, K. W. Case report: myocardial metastasis of a maxillary malignant ameloblastoma. J. Oral Maxillofac. Surg., 61:731-4, 2003.

Correspondence to:

Lucinei Roberto Oliveira

Department of Pathology

Ribeirao Preto Medical School - USP.

Avenida Bandeirantes 3900

Bairro Monte Alegre

14049-900

Ribeirão Preto

São Paulo

BRAZIL

Phone: 551636023119

Fax 551636020224

Email: lucinei@yahoo.com

Received: 24-08-2011

Accepted: 05-22-2011 